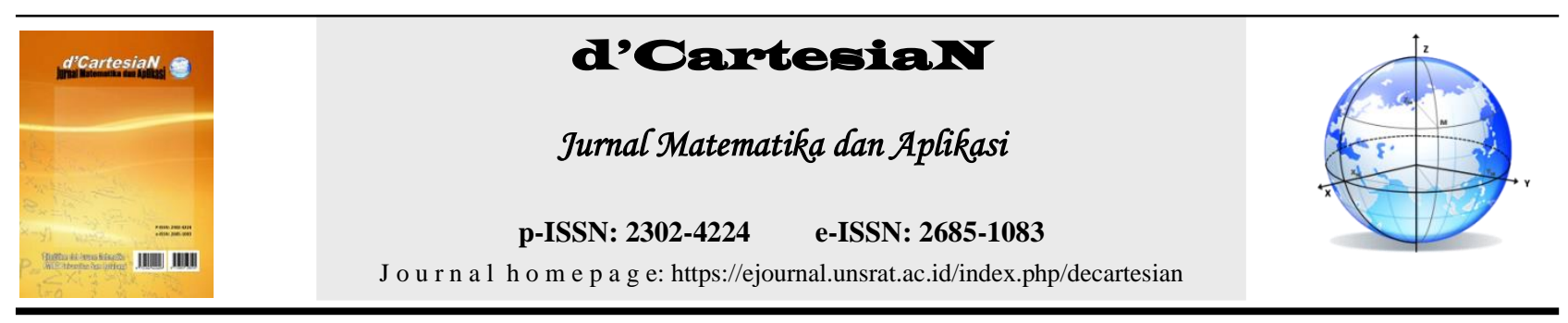

\title{
Optimasi Pembagian Tugas Karyawan Pada Bengkel Indomobil Nissan Datsun Kombos Dengan Menggunakan Metode Hungarian
}

\author{
Dewi Permata Sari' ${ }^{\prime}$, Marline S. Paendong ${ }^{{ }^{*}}$, Yohanes A. R. Langi ${ }^{1}$
}

${ }^{1}$ Jurusan Matematika-Fakultas Matematika dan Ilmu Pengetahuan Alam-Universitas Sam Ratulangi Manado, Indonesia

${ }^{*}$ Corressponding author : $\underline{\text { marlinepaendong@unsrat.ac.id }}$

\begin{abstract}
A B S T R A K
Sumber Daya Manusia adalah salah satu faktor yang sangat penting bahkan tidak dapat dilepaskan dari sebuah organisasi, institusi maupun perusahaan. Sumber Daya Manusia juga merupakan usaha yang dituntut kemampuannya dalam meningkatkan efisiensi dan mengefektifkan penggunaannya sehingga Sumber Daya Manusia merupakan kunci yang menentukan berkembangnya suatu perusahaan. Dalam Bengkel Indomobil Nissan Datsun Kombos, jenis pekerjaan yang dilakukan oleh karyawan berbeda-beda dikarenakan tingkat kemahiran atau produktifitasnya. Tujuan penelitian untuk mengetahui pembagian tugas karyawan pada Bengkel Indomobil Nissan Datsun Kombos sehingga mendapat waktu kerja yang optimal. Metode Hungarian dapat digunakan untuk mengetahui pembagian tugas karyawan sehingga mendapat waktu kerja yang optimal. Hasil pembagian tugas karyawan yang diperoleh dengan metode Hungarian jika dibandingkan dengan penempatan karyawan sebelumnya menunjukkan adanya efisiensi waktu sebanyak 191.4 menit per setiap 5
\end{abstract}

\section{INFO ARTIKEL}

Diterima : 13 Juli 2020

Diterima setelah revisi : 29 Agustus 2020

Tersedia online : 6 Januari 2021

\author{
Kata Kunci: \\ Indomobil Nissan Datsun Kombos \\ Metode Hungarian \\ Pembagian Tugas Karyawan \\ Program Linear \\ Sumber Daya Manusia
}

\begin{abstract}
A B S T R A C T
Human Resources is one of the most important factors that even cannot be separated from an organization, institution or company. Human Resources is also a business that requires its ability to increase efficiency and make it more effective so that Human Resources is the key that determines the development of a company. At the shop of Indomobil Nissan Datsun Kombos, the type of work performed by employees varies due to their level of expertise or productivity. The purpose of this study was to determine the division of work of employees at Indomobil Nissan Datsun Kombos to get an optimal work time. The Hungarian method can be used to find out the division of duty of employees so they get an optimal work time. The division results of employee duty obtained by the Hungarian method when compared with a previous placements showed a time efficiency of 191.4 minutes per every 5 workers doing 5 jobs.
\end{abstract}

\section{ARTICLE INFO :}

Received : 13 July 2020

Received after revision : 29 August 2020 Available online : 6 January 2021

\author{
Keywords: \\ Indomobil Nissan Datsun Kombos \\ The Hungarian Method \\ Division of Employee Tasks \\ Linear Programming \\ Human Resources
}

\section{PENDAHULUAN}

Sumber Daya Manusia adalah salah satu faktor yang sangat penting bahkan tidak dapat dilepaskan dari sebuah organisasi, institusi maupun perusahaan. Sumber Daya Manusia juga merupakan usaha yang dituntut kemampuannya dalam meningkatkan efisiensi dan mengefektifkan penggunaannya sehingga Sumber Daya Manusia merupakan kunci yang menentukan berkembangnya suatu perusahaan. Sumber Daya Manusia sangat berhubungan erat dengan tenaga kerja oleh karena itu adanya alokasi optimal dari berbagai macam sumber daya yang produktif.

Dalam Bengkel Indomobil Nissan Datsun Kombos, jenis pekerjaan yang dilakukan oleh karyawan berbedabeda dikarenakan tingkat kemahiran atau produktifitasnya. Perbedaan jenis pekerjaan yang dimiliki mungkin dipengaruhi oleh beberapa faktor diantaranya: kondisi fisik, pengetahuan, pengalaman, minat, jabatan, dan kepribadian karyawan tersebut. Permasalahannya adalah besarnya biaya yang dikeluarkan untuk pekerjaan tertentu berbeda-beda di setiap karyawan atau produktivitasnya berbeda untuk pekerjaan yang berbeda.

Mengetahui masalah yang ada, perusahaan harus pandai mengelola aspek produksi dan menempatkan tenaga kerjanya secara tepat. Dengan adanya penempatan tenaga kerja secara tepat maka setiap karyawan dapat bekerja sesuai bidang masing-masing dan dapat menghasilkan biaya optimal dengan menggunakan masalah penugasan. Masalah penugasan 
merupakan masalah khusus dari pemrograman linier (Linear Progamming). Ada beberapa cara untuk menyelesaikan masalah dengan model program linear, diantaranya dapat diselesaikan dengan menggunakan metode Hungarian.

\section{TINJAUAN PUSTAKA}

\section{Indomobi Nissan Datsun Kombos}

Indomobil Nissan Datsun Kombos adalah salah satu outlet Datsun di Manado dan merupakan perusahaan yang bergerak di bidang retail otomotif khususnya mobil dengan brand Nissan - Datsun.

\section{Linear Programming}

Linear Programming (LP), atau program linear merupakan salah satu teknik yang dapat membantu dalam pengambilan keputusan alokasi sumberdayasumberdaya yang terbatas dan langka secara optimum. Sumber daya-sumber daya terbatas tersebut jika dalam satu industri atau perusahaan meliputi semua faktorfaktor produksi seperti mesin-mesin, tenaga kerja, bahan mentah, modal, teknologi dan informasi [4].

\section{Riset Operasi}

Riset Operasi adalah metode untuk memformulasikan dan merumuskan permasalahan sehari-hari baik mengenai bisnis, ekonomi, sosial maupun bidang lainnya ke dalam pemodelan matematis untuk mendapatkan solusi yang optimal [6].

\section{Masalah Penugasan}

Masalah penugasan (assignment problem) adalah suatu masalah mengenai pengaturan objek untuk melaksanakan tugas, dengan tujuan meminimalkan biaya, waktu, jarak, dan sebagainya ataupun memaksimalkan keuntungan yang salah satu penyelesaiannya menggunakan metode Hungarian [3].

Masalah ini dapat dijelaskan dalam bentuk matriks opportunity $\operatorname{cost}(m=n)$ dengan ukuran matriks $m x n$. Definisi matriks biaya (cost matrix) yaitu

$$
c_{i j}=\left[\begin{array}{cccc}
c_{11} & c_{12} & \ldots & c_{1 n} \\
c_{21} & c_{22} & \ldots & c_{2 n} \\
\ldots & \ldots & \ldots & \ldots \\
c_{m 1} & c_{m 2} & \ldots & c_{m n}
\end{array}\right]
$$

Sedangkan matriks penugasan yaitu

$$
x_{i j}=\left[\begin{array}{cccc}
x_{11} & x_{12} & \ldots & x_{1 n} \\
x_{21} & x_{22} & \ldots & x_{2 n} \\
\ldots & \ldots & \ldots & \ldots \\
x_{m 1} & x_{m 2} & \ldots & x_{m n}
\end{array}\right]
$$

Tabel 1. Matriks Penugasan

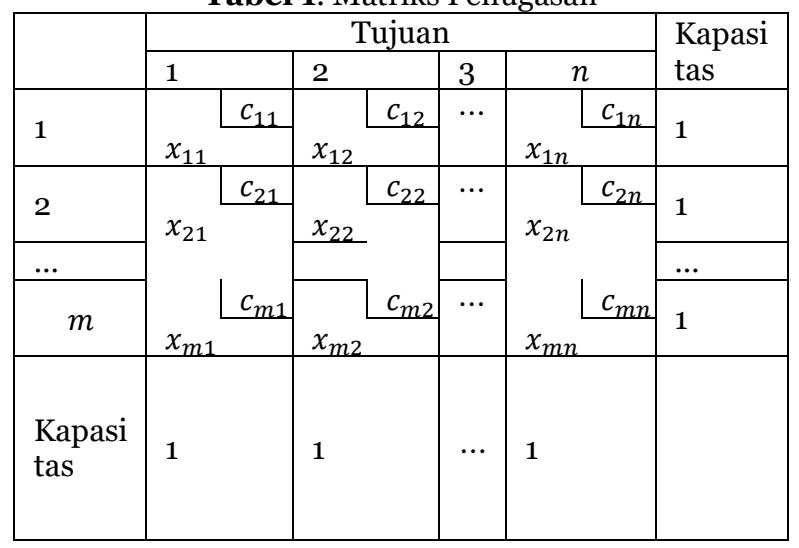

Suatu masalah umum penugasan yang hanya berkaitan dengan biaya operasi dapat direpresentasikan pada Tabel 1. Ada $n$ yang ditugaskan untuk $m$ pekerja, sedangkan adalah biaya operasi pekerja $i$ untuk melaksanakan tugas $j$.

Secara matematis masalah penugasan dapat dinyatakan dalam bentuk variabel keputusan $x_{i j}$ yaitu $x_{i j}=1$, apabila objek $i$ ditugaskan untuk tugas $j$ $x_{i j}=0$, apabila objek $i$ tidak ditugaskan untuk tugas $j$ Secara mendetail model untuk masalah penugasan dapat ditulis sebagai berikut

Meminimumkan $Z=\sum_{i=1}^{m} \sum_{j=1}^{n} c_{i j} x_{i j}$ Dengan kendala :

$$
Z=c_{11} x_{11}+c_{22} x_{22}+\cdots+c_{m n} x_{m n}
$$

$$
\begin{gathered}
\sum_{i=1}^{m} x_{i j}=1, \text { untuk } j=1,2,3, \ldots, m \\
\sum_{j=1}^{n} x_{i j}=1, \text { untuk } i=1,2,3, \ldots, n \\
x_{i j} \geq 0 \text { untuk semua } i \text { dan } j
\end{gathered}
$$

\section{Metode Hungarian}

Metode Hungarian adalah metode yang memodifikasi baris dan kolom dalam matriks efektifitas sampai muncul sebuah komponen nol tunggal dalam setiap baris atau kolom yang dapat dipilih sebagai alokasi penugasan [2].

Syarat-syarat metode Hungarian yaitu

1. Jumlah $i$ harus sama dengan jumlah $j$ yang harus diselesaikan.

2. Setiap sumber hanya mengerjakan satu tugas.

3. Apabila jumlah sumber tidak sama dengan jumlah tugas atau sebaliknya, maka ditambahkan variabel dummy woker atau dummy job.

4. Terdapat dua permasalahan yang diselesaikan yaitu meminimumkan kerugian (biaya, waktu, jarak dan sebagainya) atau memaksimumkan keuntungan [5].

Langkah-langkah penyelesaian metode Hungarian adalah:

1. Memodifikasi tabel penugasan ke dalam matriks efektifitas. Dimana matriks ini dibentuk untuk memudahkan dalam proses penyelesaian setiap langkah metode yang telah dilakukan.

2. Memilih nilai terkecil dari setiap baris, lalu dilakukan operasi pengurangan dari tiap nilai di baris tersebut dengan bilangan terkecil yang telah dipilih. Dengan demikian, dapat dipastikan bahwa ada minimal satu buah elemen di tiap baris matriks yang bernilai nol dan tidak ada elemen dengan nilai negatif.

3. Melakukan pengurangan kolom jika terdapat kolom yang belum memiliki elemen o yaitu memilih nilai terkecil dari kolom, lalu dilakukan operasi pengurangan dari tiap nilai kolom dengan bilangan terkecil yang telah dipilih. Dengan demikian, dapat dipastikan bahwa ada minimal satu buah elemen di tiap baris dan tiap kolom matriks yang bernilai nol dan tidak ada elemen dengan nilai negatif.

4. Membentuk penugasan optimum yaitu dengan menarik sejumlah garis horizontal dan atau vertikal yang melewati seluruh sel yang bernilai o. Jika jumlah garis sama dengan jumlah baris/kolom maka penugasan telah optimal. Jika tidak maka harus direvisi. 
5. Melakukan revisi tabel dengan memilih nilai terkecil yang tidak dilewati garis lalu kurangkan dengan semua nilai yang tidak dilewati garis. Kemudian ditambahkan pada angka yang terdapat pada persilangan garis. Kembali ke langkah 5 .

6. Penugasan ditempatkan pada sel yang bernilai o. Dimana Tiap angka o diganti dengan angka 1 tetapi tiap kolom dan baris hanya memiliki satu angka 1 sebagai penugasan.

7. Menghitung total nilai dari solusi yang diperoleh berdasarkan elemen dari matriks awal yang belum direduksi nilainya sehingga diperoleh total nilai optimum [1].

\section{METODE PENELITIAN}

\section{Waktu dan Tempat Penelitian}

Penelitian ini dilaksanakan pada bulan November 2019 - Juli 2020, bertempat pada Indomobil Nissan Datsun Kombos. Selanjutnya pengelolaan data dilakukan di Laboratorium Statistika Jurusan Matematika, FMIPA UNSRAT.

\section{Sumber Data}

Data yang digunakan dalam penelitian ini adalah menggunakan data sekunder yang diperoleh dari Indomobil Nissan Kombos. Data yang diambil berupa data jam kerja karyawan dalam menyelesaikan kerusakan setiap mobil yang ada Indomobil Nissan datsun Kombos.

\section{Langkah-Langkah Penelitian}

1. Meminta surat pengambilan data dari Jurusan Matematika Unsrat.

2. Mengantar surat ke Indomobil Nissan Datsun Kombos.

3. Bertemu dengan kepala bengkel dan menjelaskan data apa yang akan diambil.

4. Mengambil data dari Bengkel Indomobil Nissan Kombos.

- Jenis pekerjaan karyawan

- Jam kerja yang dibutuhkan setiap karyawan dalam menyelesaikan setiap pekerjaan

5. Membuat model matematiknya.

6. Menyusun data ke dalam bentuk matriks efektifitas.

7. Mencari solusi optimal dengan menggunakan metode Hungarian untuk memastikan apakah pembagian tugas karyawan sudah tepat atau belum.

8. Mendapatkan hasil.

9. Pembahasan dan Kesimpulan.

\section{HASIL DAN PEMBAHASAN}

\section{Deskripsi Data}

Penelitian ini dilakukan di Bengkel Nissan Datsun Kombos yang berada di kota Manado. Alamat lengkap Bengkel Indomobil Nissan Datsun yaitu Kombos Tim., Kec. Singkil, Kota Manado, Sulawesi Utara.

Perusahaan ini memiliki teknisi mobil sebanyak 5 karyawan. Setiap karyawan memperoleh tugas dengan waktu kerja setiap hari Senin - Sabtu yang dimulai pada pukul o8:30 Wita sampai pukul 16:30 Wita.
Data yang diambil dari Bengkel Nissan Datsun Kombos ini yaitu waktu penyelesaian yang digunakan dari setiap karyawan untuk menyelesaikan kerusakan pada satu mobil disajikan pada tabel 2.

Tabel 2. Waktu Menyelesaikan Pekerjaan pada setiap Jenis Mobil (dalam Menit)

\begin{tabular}{|c|l|l|l|l|l|}
\hline \multirow{2}{*}{$\begin{array}{c}\text { JENIS } \\
\text { PEKERJAAN }\end{array}$} & \multicolumn{5}{|c|}{ KARYAWAN } \\
\cline { 2 - 6 } & T1 & T2 & T3 & T4 & T5 \\
\hline A & 96 & 54 & 108 & 120 & 72 \\
\hline B & 162 & 162 & 108 & 108 & 162 \\
\hline C & 126 & 120 & 198 & 186 & 222 \\
\hline D & 75 & 78 & 30 & 150 & 60 \\
\hline E & 90 & 150 & 150 & 60 & 150 \\
\hline
\end{tabular}

Keterangan : A = Service Interval $10.000 \mathrm{Km}, \mathrm{B}=$ Service Interval $20.000 \mathrm{Km}, \mathrm{C}=$ Service Interval $40.000 \mathrm{Km}, \mathrm{D}=$ Service Kecil \& Ganti Oil Filter, E = Tune Up, dan $\mathrm{T}=$ Teknisi

Sebelum menggunakan metode Hungarian, penugasan optimal menyelesaikan kerusakan mobil dapat dilihat dari waktu rata-rata penyelesaian dari setiap masing-masing pekerjaan.

Tabel 3. Waktu rata-rata sebelum menggunakan metode Hungarian

\begin{tabular}{|c|c|}
\hline JENIS PEKERJAAN & WAKTU (Menit) \\
\hline A & 90 \\
\hline B & 140.4 \\
\hline C & 170.4 \\
\hline D & 78.6 \\
\hline E & 120 \\
\hline & \\
TOTAL WAKTU OPTIMAL & $\mathbf{5 9 9 . 4}$ \\
\hline
\end{tabular}

Total waktu optimal yang diperoleh Bengkel Indomobil Nissan Datsun Kombos dalam setiap jenis pekerjaan adalah 599.4 menit sebelum menggunakan metode Hungarian.

\section{Analisis Data}

Berdasarkan Tabel 2, untuk menyelesaikan optimalisasi masalah penugasan pada Bengkel Indomobil Nissan Datsun Kombos, masalah diformulasikan ke dalam pemrograman linear terlebih dahulu dan diperoleh persamaan sebagai berikut : Meminimumkan $Z=\sum_{i=1}^{5} \sum_{j=1}^{5} c_{i j} x_{i j}$

$$
\begin{aligned}
Z= & 96 x_{1,1}+54 x_{1,2}+108 x_{1,3}+120 x_{1,4}+72 x_{1,5}+ \\
& 162 x_{2,1}+162 x_{2,2}+108 x_{2,3}+108 x_{2,4}+ \\
& 162 x_{2,5}+126 x_{3,1}+120 x_{3,2}+198 x_{3,3}+ \\
& 186 x_{3,4}+222 x_{3,5}+75 x_{4,1}+78 x_{4,2}+ \\
& 30 x_{4,3}+150 x_{4,4}+60 x_{4,5}+90 x_{5,1}+ \\
& 150 x_{5,2}+150 x_{5,3}+60 x_{5,4}+150 x_{5,5}
\end{aligned}
$$

Fungsi Kendala Karyawan : 


$$
\begin{aligned}
& x_{1,1}+x_{1,2}+x_{1,3}+x_{1,4}+x_{1,5}=1 \\
& x_{2,1}+x_{2,2}+x_{2,3}+x_{2,4}+x_{2,5}=1 \\
& x_{3,1}+x_{3,2}+x_{3,3}+x_{3,4}+x_{3,5}=1 \\
& x_{4,1}+x_{4,2}+x_{4,3}+x_{4,4}+x_{4,5}=1 \\
& x_{5,1}+x_{5,2}+x_{5,3}+x_{5,4}+x_{5,5}=1
\end{aligned}
$$

Fungsi Kendala Jenis Kerusakan :

$$
\begin{aligned}
& x_{1,1}+x_{2,1}+x_{3,1}+x_{4,1}+x_{5,1}=1 \\
& x_{1,2}+x_{2,2}+x_{3,2}+x_{4,2}+x_{5,2}=1 \\
& x_{1,3}+x_{2,3}+x_{3,3}+x_{4,3}+x_{5,3}=1 \\
& x_{1,4}+x_{2,4}+x_{3,4}+x_{4,4}+x_{5,5}=1 \\
& x_{1,5}+x_{2,5}+x_{3,5}+x_{4,5}+x_{5,5}=1
\end{aligned}
$$

Berdasarkan tabel 2, untuk mengetahui pengoptimalan dengan meminimumkan waktu penyelesaian pekerjaan dengan langkah-langkah sebagai berikut :

1. Membuat tabel dalam bentuk matriks efektifitas. Matriks dalam penugasan ini adalah matriks $5 \times 5$.

$$
\left(\begin{array}{ccccc}
96 & 54 & 108 & 120 & 72 \\
162 & 162 & 108 & 108 & 162 \\
126 & 120 & 198 & 186 & 222 \\
75 & 78 & 30 & 150 & 60 \\
90 & 150 & 150 & 60 & 150
\end{array}\right)
$$

Untuk setiap baris, kurangkan entri terkecil dalam setiap baris pada matriks tersebut. Entri terkecil dari baris pertama yaitu 54, entri terkecil dari baris kedua yaitu 108, entri terkecil dari baris ketiga yaitu 120, entri terkecil dari baris keempat yaitu 30 dan entri terkecil dari baris kelima yaitu 60.

2. Mengurangi semua entri dalam baris dengan entri terkecil.

$$
\left(\begin{array}{ccccc}
42 & 0 & 54 & 66 & 18 \\
54 & 54 & 0 & 0 & 54 \\
6 & 0 & 78 & 66 & 102 \\
45 & 48 & 0 & 120 & 30 \\
30 & 90 & 90 & 0 & 90
\end{array}\right)
$$

Dari hasil pengurangan entri pada setiap baris, terdapat dua kolom yang tidak mempunyai entri o yaitu kolom pertama dan kolom kelima. Sehingga perlu dilakukan pengurangan entri pada kolom pertama dan kolom kelima yaitu pada baris kolom pertama dikurang 6 dan kolom kelima dikurang 18 .
3. Mengurangi semua entri dalam kolom dengan entri terkecil.

$$
\left(\begin{array}{lllll}
36 & 0 & 54 & 66 & 0 \\
48 & 54 & 0 & 0 & 36 \\
0 & 0 & 78 & 66 & 84 \\
39 & 48 & 0 & 120 & 12 \\
24 & 90 & 90 & 0 & 72
\end{array}\right)
$$

Setelah melakukan pengurangan dari entri terkecil dari setiap baris dan kolom akan dilakukan penugasan optimum sehingga jumlah garis yang menutupi nilai o sama dengan perkalian matriks.

4. Membentuk penugasan optimum yaitu dengan menarik sejumlah garis horizontal dan atau vertikal yang melewati seluruh sel yang bernilai o.

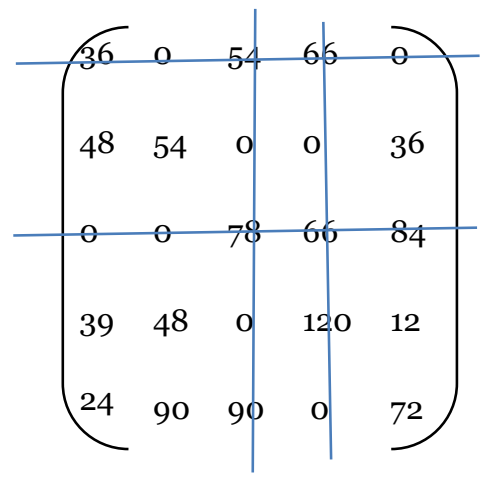

5. Karena matriks pada langkah 4 menunjukan bahwa garis yang menutupi semua entri o belum sama dengan jumlah baris/kolom, maka dilakukan revisi tabel dengan memilih nilai terkecil yang tidak dilewati garis lalu kurangkan dengan semua nilai yang tidak dilewati garis. Kemudian ditambahkan pada angka yang terdapat pada persilangan garis. Setelah itu, menarik kembali sejumlah garis horizontal atau vertical yang melewati seluruh sel yang bernilai 0 .

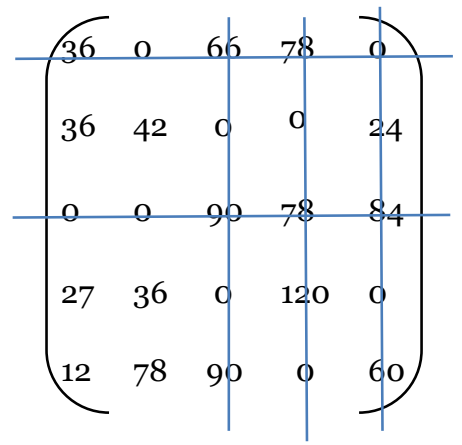


6. Matriks pada langkah 5 menunjukkan bahwa jumlah garis yang menutupi semua entri $o$ sudah sama dengan jumlah baris/kolom, sehingga penugasan sudah optimal. Oleh karena itu, penentuan penugasan sudah dapat dilakukan, dimulai dari baris/kolom yang hanya mempunyai satu nilai 0 .

$$
\begin{gathered}
\text { Solusi/keputusan yang diperoleh adalah } \\
x_{1,2}=x_{2,3}=x_{3,1}=x_{4,5}=x_{5,4}=1
\end{gathered}
$$

Dengan menyesuaikan variabel hasil keputusan, maka diperoleh total waktu (minimal) yang dibutuhkan untuk menjahit pakaian tersebut yaitu :

$$
\begin{aligned}
Z & =x_{1,2}+x_{2,3}+x_{3,1}+x_{4,5}+x_{5,4} \\
& =54+108+126+60+60 \\
& =408 \text { Menit }
\end{aligned}
$$

Berdasarkan hasil perhitungan menggunakan metode

\begin{tabular}{|c|c|c|}
\hline $\begin{array}{c}\text { JENIS } \\
\text { PEKERJAAN }\end{array}$ & KARYAWAN & $\begin{array}{l}\text { WAKTU } \\
\text { (MENIT) }\end{array}$ \\
\hline A & T2 & 54 \\
\hline B & $\mathrm{T} 3$ & 108 \\
\hline $\bar{C}$ & T1 & 126 \\
\hline $\mathrm{D}$ & $\mathrm{T} 5$ & 60 \\
\hline $\bar{E}$ & $\mathrm{~T}_{4}$ & 60 \\
\hline \multicolumn{2}{|c|}{ TOTAL WAKTU OPTIMAL } & 408 \\
\hline
\end{tabular}
Hungarian diperoleh total waktu optimal yaitu 408 menit, dengan pengaturan penugasan sebagai berikut.

Tabel 4. Total waktu optimal menggunakan metode Hungarian

Setelah menggunakan metode Hungarian total waktu optimal yang didapat 408 menit yaitu dengan penempatan tugas jenis perkerjaan A (Service Interval $10.000 \mathrm{Km}$ ) dikerjakan oleh karyawan T2 dengan waktu 54 menit, jenis pekerjaan B (Service Interval 20.000 $\mathrm{Km}$ ) dikerjakan oleh karyawan $\mathrm{T}_{3}$ dengan waktu 108 menit, jenis pekerjaan C (Service Interval $40.000 \mathrm{Km}$ ) dikerjakan oleh karyawan T1 dengan waktu 126 menit, jenis pekerjaan D (Service Kecil dan Ganti Oil Filter) dikerjakan oleh karyawan $\mathrm{T}_{5}$ dengan waktu 60 menit, dan jenis pekerjaan $\mathrm{E}$ (Tune Up) dikerjakan oleh karyawan T4 dengan waktu 60 menit. Sehingga jika dibandingkan antara penempatan karyawan sebelumnya dengan menempatkan karyawan berdasarkan metode Hungarian, ternyata terjadi efisiensi waktu sebanyak 191.4 menit per setiap 5 pekerja melakukan 5 pekerjaan.

\section{PENUTUP}

\section{Kesimpulan}

Pembagian tugas karyawan yang tepat sehingga menghasilkan biaya optimal adalah jenis perkerjaan A dikerjakan oleh karyawan $\mathrm{T} 2$, jenis pekerjaan $\mathrm{B}$ dikerjakan oleh karyawan $\mathrm{T}_{3}$, jenis pekerjaan $\mathrm{C}$ dikerjakan oleh karyawan $\mathrm{T} 1$, jenis pekerjaan $\mathrm{D}$ dikerjakan oleh karyawan $\mathrm{T}_{5}$, dan jenis pekerjaan $\mathrm{E}$ dikerjakan oleh karyawan T4. Hasil optimal sebelum menggunakan metode Hungarian adalah 599.4 menit dan hasil optimal setelah menggunakan metode Hungarian adalah 408 menit, sehingga jika dibandingkan antara penempatan karyawan sebelumnya dengan menempatkan karyawan berdasarkan metode Hungarian, ternyata terjadi efisiensi waktu sebanyak 191.4 menit per setiap 5 pekerja melakukan 5 pekerjaan.

\section{REFERENSI}

[1] Paendong, M. 2011. Optimasi Pembagian Tugas Menggunakan Metode Hungarian. Jurnal Ilmiah Sains 11 (1) : 110-111.

[2] Prawirosentono, S. 2005. Riset Operasi dan Ekonofisika. PT. Bumi Aksara, Jakarta.

[3] Soemartojo, N. 1997. Program Linear. Depdikbud Direktorat Jenderal Pendidikan Dasar dan Menengah, Jakarta.

[4] Syaifuddin, D. T. 2011. Riset Operasi (Aplikasi Quantitative Analysis For Management). Edisi ke1. CV Citra Malang, Malang.

[5] Taha, A.H. 1996. Riset Operasi Jilid I. Binarupa Aksara. Jakarta.

[6] Yuwono, B. dan Istiani, N. P. 2007. Bahan Kuliah Riset Operasional. UPN "Veteran", Yogyakarta

\section{Dewi Permata Sari (dewisario809@gmail.com)}

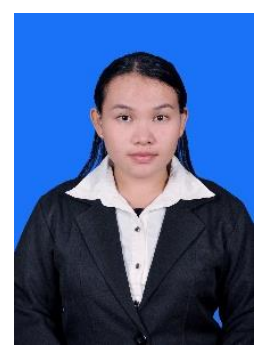
Lahir di Pematang Panjang, Sumatera Utara, pada tanggal o8 September 1998. Menempuh pendidikan tinggi Jurusan Matematika, FMIPA, Universitas Sam Ratulangi Manado. Tahun 2020 adalah tahun terakhir ia menempuh studi. Makalah ini merupakan hasil penelitian skripsinya yang dipublikasikan.

Marline S. Paendong (marlinepaendong@unsrat.ac.id)

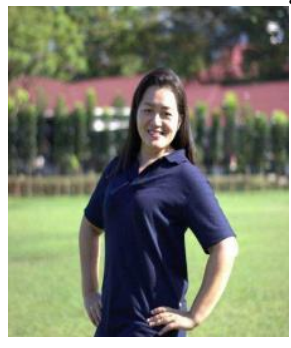
Pada tahun 1999, memperoleh gelar sarjana di Program Studi Matematika, Universitas Gadjah Mada. Gelar Sarjana Sains (S.Si) diperoleh dari Universitas Gadjah Mada pada tahun 2006. Gelar Magister Sains diperoleh di Institut Pertanian Bogor pada tahun 2006. Ia bekerja di UNSRAT di Program Studi Matematika sebagai pengajar akademik tetap dan bekerja di Kantor Rektor UNSRAT sebagai Lektor.

Yohanes A. R. Langi (yarlangi@gmail.com)

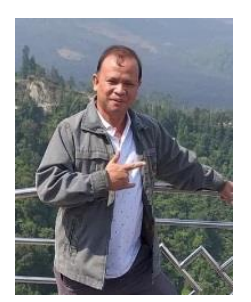

Lahir di Jakarta pada tanggal 13 Juni 1970. Pada tahun 1994 mendapatkan gelar Sarjana Sains (S.Si) yang diperoleh dari Universitas Kristen Indonesia - Tomohon. Gelar Master Sains (M.Si) diperoleh dari Institut Pertanian Bogor pada tahun 2007. Ia bekerja di UNSRAT di Program Studi Matematika sebagai pengajar akademik tetap UNSRAT. 